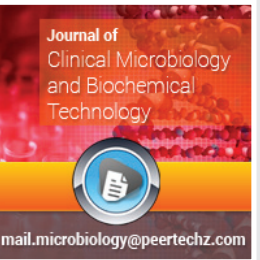

Clinical Group

\title{
Journal of Clinical Microbiology and Biochemical Technology
}

\section{S Rajeshwari and SP Sevarkodiyone}

Department of Zoology, Ayya Nadar Janaki Ammal College (Autonomous) Sivakasi, Tamil Nadu - 626 124, India

Dates: Received: 15 December, 2017; Accepted: 29 December, 2017; Published: 30 December, 2017

*Corresponding author: S Rajeshwari, Department of Zoology, Ayya Nadar Janaki Ammal College (Autonomous) Sivakasi, Tamil Nadu - 626 124, India,

E-mail: rajieswari07@gmail.com

Keywords: Cadmium; Biochemical parameters; Cyprinus carpio

https://www.peertechz.com
Research Article

Biochemical parameters of Common

Carp (Cyprinus Carpio) exposed to Cadmium change to the leaf extract of Abutilon indicum

\section{Introduction}

Aquaculture is one of the important sectors contributing significantly to the Indian economy. Fish culturists are encouraged towards intensification of culture system to increase production and profit. In such practice of fish and shrimp farming, disease becomes major threats. The disease is one of the most important constraints of fish production both in culture system, as well as wild condition. Fish production is decreased due to the occurrence of disease caused by different pathogen in aquaculture [1]. Heavy metals may enter into aquatic ecosystems and induce stress symptoms in fish. Some metals are essential since they play an important role in biological systems, while some others are nonessential metals as they have no known role in biological systems $[2,3]$. One of the most important characteristics of toxic pollutants such as metals is that they can be accumulated in organs of the organisms [4]. Fish have been largely used in the evaluation of the quality of aquatic systems. These organisms are often at the top of the aquatic food chain and may concentrate large amount of metals from the surrounding waters [5]. The accumulation of metals in aquatic systems suggests that fish may serve as a useful indicator of contaminating metals in aquatic systems, since they respond with great sensitivity to changes in the aquatic environment $[6,7]$. Cadmium is used as metal protecting coating for Iron, sease and steel. Cadmium electroplated rods are used in radio and television. It is also used in storage of batteries, photography, ceramic industry, lithography, petroleum refineries and phosphate fertilizer industries [8]. Cadmium is divalent metal toxicant and is a toxic environmental and industrial pollutant. The toxicity of cadmium became oblivious within its increasing use [9]. Cadmium is one of the most toxic heavy metals with a wide distribution. Estimation of responses to heavy metals may provide sensitive indicators on which to predict the effects of heavy-metal pollution on fish populations [10]. The heavy metal in the tissue of fishes may cause various physiological defects and mortality [11]. The fishes which are largely being used for the assessment of the quality of the aquatic environment and can cause bio indicator of environmental pollute [12]. Hence, the present study has been carried out the Biochemical parameters of common cap cyprinus carpio exposed to cadmium in control to this plant extract of Abutilon indicum.

\section{Materials and Methods}

Chemical: Heavy metal cadmium has purchased from High Media Chemicals, India Private Limited, India.

\section{Experimental Setup}

A live fish (12 $\pm 1 \mathrm{~g}$ ) were collected from the High-tech fish farm, Madurai, Tamil Nadu, India. The fishes were maintained 
in non-chlorinated water in 20 days. The ground nut oil cake, fish meal and rice bran, tapioca, soybean, were mixeds and sterilized and mixed to amultivitamin tablet and different concentrations 1ppm, 2ppm and 3ppm) of Abutilon indicum extract used for experimental fishes and without plant extract diet for control fish. The food was made into small pellets. In every eight in days following biochemical studies such as, (Table 1).

\section{Biochemical Studies}

Blood samples for the estimation of glucose, and protein, both from acute and sublethal treatments, were obtained as outlined in the material and methods section of chapter II of this thesis. Biochemical components such as plasma glucose and protein were estimated in fish to assess the secondary stress responsiveness.

\section{Glucose}

True enzymatic glucose was estimated according to the method of [13-15] enzymatically by glucose oxidase/ peroxidase method by Autozyme glucose diagnostic reagent kit manufactured by Accurex Biomedical, Bombay, India (Code GU-3s) using Technicon RA-500 (Technicon Instruments Corporation, Tarrytown, New York, USA).

\section{Principle}

Glucose oxidase (GOD) converts glucose to gluconic acid. Hydrogen peroxide formed in this reaction, in presence of peroxidase (POD), oxidatively couples with 4-aminoantipyrine/phenol to produce red quinoneimine dye. This dye has absorbance maximum at $505 \mathrm{~nm}(500-550 \mathrm{~nm})$. The intensity of the colour complex is directly proportional to the glucose in specimen.

\section{The reaction can be represented as follows:}

\section{GOD}

B-D Glucose $+02+\mathrm{H} 20------>$ Gluconic Acid $+\mathrm{H} 202$
POD
$+\mathrm{H} 20$

H202 + 4-amino- antipyrine + Phenol-------> Red Dye

\section{REAGENTS}

Reagent 1: Enzyme vial

Reagent 2: Diluent reagent

Reagent 3: Standard glucose reagent $(100 \mathrm{mg} / \mathrm{dL})$

\section{Solution A}

Working Solution: The contents of enzyme vials were transferred into the working solution bottle and mixed with the diluent reagent gently by swirling or inversion taking care to avoid shaking vigorously,

\section{Components and Concentration of Working Solution}

Phosphate buffer, pH 7.0 - $170.00 \mathrm{mmol} / \mathrm{L}$

Glucose oxidase - 5000.00 IU/L

Peroxidase - $3000.00 \mathrm{IU} / \mathrm{L}$

4-aminoantipyrine $-0.28 \mathrm{mmol} / \mathrm{L}$

Phenol - $16.00 \mathrm{mmol} / \mathrm{L}$

Stabilisers and inactive ingredients

\section{Procedure}

The Technicon RA-500 System, a computer-controlled, random access clinical chemistry analyser system was set-up for the analysis of true enzymatic glucose in the plasma. Before starting the experiments, the calibration factor was found out. This value was determined via, a calibrator assay according to the instructions in the chemistry program data sheet for in vitro measurement of enzymatic glucose in the Technicon method manual of Technicon RA-500 System. It is enough if the calibration and program setting is done for one time before running the experiments. Then the working solution (Solution A) was placed in the reagent tray and the plasma from control and experimental groups was placed in appropriate grooves of the sample tray. After this, 2 function and idee number (given according to our convenience so as to identify the sample) were operated to enter word list and download the word list by giving a particular assay code. Now the Technicon RA-500 System operates automatically and 375 jil of solution A for each sample and 7.5 pi of plasma from the respective vials were added separately to the respective fixed cuvettes in the reaction tray. The contents were incubated for $30 \mathrm{sec}$. and the absorbance of the samples was measured individually, calculated as given below, by the computing unit and the true enzymatic glucose level in $\mathrm{mg} / \mathrm{dL}$ was printed out within $1 \mathrm{~min}$.

\section{Calculation}

True enzymatic glucose in $\mathrm{mg} / \mathrm{dL}$ was calculated as follows: Reported result in $\mathrm{mg} / \mathrm{dL}=\frac{\text { Assay Result } \mathrm{x} \text { Unit Factor }- \text { Intercept }}{\text { Slope }}$

Table 1: Changes in biochemical parameters of plant extract Abutilon indicum using Cyprinus carpio exposed to varying periods of sub lethal concentrations of cadmium

\begin{tabular}{|c|c|c|c|c|c|c|c|c|c|}
\hline & \multirow{3}{*}{$\begin{array}{l}\text { Dose } \\
\text { ppm }\end{array}$} & \multicolumn{3}{|c|}{ Total Glucose(mg/dl) } & \multicolumn{5}{|c|}{ Total Protein(mg/dL) } \\
\hline & & \multicolumn{8}{|c|}{ Exposure Period (days) } \\
\hline & & 0 & 10 & 20 & 30 & 0 & 10 & 20 & 30 \\
\hline Normal fish & 0 & $15 . .46 \pm 0.53$ & $15.84 \pm 0.03$ & $16.09 \pm 0.92$ & $16.72 \pm 0.80$ & $20.30 \pm 0.52$ & $20.48 \pm 0.52$ & $21.50 \pm 0.19$ & $21.70 \pm 0.90$ \\
\hline Control(Cadmium treated fish) & 0 & $14.20 \pm 0.25$ & $13.06 \pm 0.63$ & $13.92 \pm 0.28$ & $12.60 \pm 1.22$ & $19.73 \pm 0.52$ & $18.92 \pm 0.70$ & $17.14 \pm 0.57$ & $16.43 \pm 0.33$ \\
\hline \multirow{3}{*}{ Exp.fish (Cadmium+Abutilon indicum) } & 0.2 & $16.43 \pm 0.33$ & $16.82 \pm 0.68$ & $17.14 \pm 0.57$ & $17.46 \pm 0.46$ & $20.80 \pm 1.22$ & $21.20 \pm 0.69$ & $21.33 \pm 1.07$ & $22.40 \pm 0.67$ \\
\hline & 0.4 & $16.92 \pm 0.72$ & $17.1 \pm 0.13$ & $18.2 \pm 0.70$ & $18.92 \pm 1.23$ & $21.09 \pm 0.93$ & $22.60 \pm 0.23$ & $23.43 \pm 0.34$ & $23.60 \pm 0.92$ \\
\hline & 0.6 & $17.19 \pm 0.89$ & $18.03 \pm 1.30$ & $19.26 \pm 0.77$ & $19.73 \pm 0.52$ & $21.62 \pm 0.46$ & $22.10 \pm 0.68$ & $23.96 \pm 0.96$ & $24.06 \pm 1.23$ \\
\hline
\end{tabular}


Where,

\section{Assay result $=$ Calibration Factor $\mathrm{x}$ Assay Absorbance}

\section{Protein}

Total protein concentration was estimated by Biuret method as described by $[16,17]$ using Autopak protein diagnostic reagent kit manufactured and supplied by Miles India Ltd., Baroda, India (Code 6370) by Technicon RA-500 System (Technicon Instruments Corporation, Tarrytown, New York, USA).

\section{Principle}

Peptide bonds of protein form a blue-violet coloured complex with cupric ions in an alkaline medium. The intensity of the colour is proportional to the number of peptide bonds and the colour is read at $540 \mathrm{~nm}(530-570 \mathrm{~nm})$. The final colour is stable for 8 hours.

\section{Reagents}

Reagent 1: Biuret reagent

Reagent 1A: Surfactant reagent

Reagent 2: Standard albumin reagent $(7 \mathrm{~g} / \mathrm{dL})$

\section{Solution A}

Working Solution: To whole volume of biuret reagent (Reagent 1), $81.00 \mathrm{ml}$ of distilled water was added then, the whole volume of surfactant reagent (Reagent $1 \mathrm{~A}$ ) was added and mixed gently to avoid foaming.

\section{Procedure}

The Technicon RA-500 System, a computer-controlled, random access clinical chemistry analyser system was setup for the analysis of total plasma protein concentration. For this, first the calibration factor was determined. This value was determined via, a calibrator assay according to the instruction in the chemistry program data sheet for in vitro measurement of total protein in the Technicon method manual of Technicon RA-500 System. Once if the calibration and program setting is done for the first time, the instrument will operate according to the feeded values till the calibration is done for a second time. After setting the instrument, the working solution (Solution A) was placed in the reagent tray and the sample from control and experimental groups was placed in appropriate grooves of the sample tray. Then, 2 function was operated followed by idee number (according to our convenience so as to identify the sample) in order to download the word list by giving a particular assay code. When the word list has been entered and operate command has been given, the Technicon RA-500 System operates automatically and 375 pi of Solution A for each test and 7.5 jul of sample from the respective vials were added to the reaction tray containing fixed cuvettes. The absorbance of the samples was measured, calculated as given below by the computing unit and the total protein concentration in $\mathrm{g} / \mathrm{dL}$ was reported as printed matter within 2 min.

\section{Calculation}

Total protein concentration in $\mathrm{g} / \mathrm{dL}$ was calculated as follows:

Reported result in $\mathrm{g} / \mathrm{dL}=\frac{\text { Assay Result } \mathrm{x} \text { Unit Factor }- \text { Intercept }}{\text { Slope }}$

Where,

Assay result $=$ Calibration Factor $\mathrm{x}$ Assay Absorbance

\section{Results}

In the present study the biochemical parameters a glucose and protein were studied in disease induced Cyprinus carpio using different concentrations of Abutilon indicum plant extract. Biochemical parameters on disease induced Cyprinus carpio fed with different concentration were (oday to 30 days). The plasma glucose level increased in the experimental fish, registering a per cent elevation of $19.26 \pm 0.77$ at the end of period. On the other hand, plasma protein in the treated fish recorded a per cent decrease of $24.06 \pm 1.23$ at the end of the treatment. All the two parameters were significantly different from that of their respective controls when the date were analysed by't' test.

\section{Total Glucose}

Total Glucose level in serum of the common carp, Cyprinus carpio during sublethal exposure to cadmium toxicity recorded overall elevations in its activity level over that of the control (Table-1). The increase of serum glucose was directly proportional to the exposure periods showing a minimum percentage increase of $17.19 \pm 0.89$ at the end of 30th day and a maximum percent increase of $19.73 \pm 0.52$ at the end of 3ond day of treatment.

\section{Total Protein}

Total Protein level in serum of common carp exposed to sublethal concentration of cadmium toxicity was found to be decreased moderately in experimental fish than the control (Table-1). The decrease of serum protein was directly proportional to the exposure periods. At the end of oth day, minimum percent decrease of $21.62 \pm 0.46$ and a maximum percent decrease of $24.06 \pm 1.23$ at the end of 30nd day of treatment were recorded.

\section{Discussion}

The present study demonstrated that the common carp, Cyprinus carpio exposed to sublethal concentrations of cdmium displayed a significant elevation in the level of blood glucose after all the exposure periods. Similar observations have been reported [18-20], in fish and rat treated with cadmium. Additionally significant hyperglycemia were in the catfish, Heteropneustes fossilis exposed to nickel [21]. in the fish Labeo rohita and Claries gariepinus subjected to copper and in the teleost, Oreochromis mossambicus exposed to lead [22]. have attributed hyperglycemic in fishes exposed to various pollutants to stress induced adrenocortisol hormone release. The elevation of glucose may be because of the stress induced by pesticide on physiology of organisms with the help of 
corticosteriods, resulting in hyperglycemic conditions [23]. observed a significant increase in serum cortisol and glucose associated with exposure to both organic and inorganic chemicals. The authors further reported that the rapid rise in glucose results from glycogenolysis release of glycogen reserves in muscle and liver) initiated by catecholamines, while sustained elevation of serum glucose are maintained by cortisol stimulated gluconeogenesis.lA similar mechanism may be operating in the present study also.

Plasma proteins were decreased significantly with exposure period of chromium. This could be attributed to renal excretion or impaired protein synthesis or due to liver disorder on the other hand, the observed decrease of plasma protein could also result from the breakdown of protein into amino acids first and possibly into nitrogen and other elementary molecules. Similar reduction in protein has also been reported in Saccobranchus fossils following exposure to chlordane [24]. Reported that there is an appreciable decline in different biochemical constituents in various tissues in fresh water fish Labeo rohita under chromium stress [25]. reported that the plasma protein was lowered when Heterobranchus bidorsalis and Clarias gariepinus were exposed to sublethal effect of cadmium toxicity.

\section{Acknowledgement}

The authors thanks the Management, Principal and Head of the Department of Zoology, Ayya Nadar Janaki Ammal College, Sivakasi for providing facilities to carry out this research work.

\section{References}

1. Sivasankar $P$, Santhiya AVA, Kanaga $V$ (2015) a review on plants and herbal extracts against viral diseases in aquaculture. Journal of Medicinal Plants Studies 3: 75-79. Link: https://goo.gl/FGL31 J

2. Rainbow PS, White SL (1989) Comparative strategies of heavy metal accumulation by crustaceans: zinc, copper and cadmium in a decapod, an amphipod and a barnacle. Hydrobiol 174: 245-262. Link: https://goo.gl/jYfgv5

3. Sanders MJ (1997) A field evaluation of the freshwater river crab, Potamonauteswarreni, as a bio-accumulative indicator of metal pollution. M. Sc: Thesis, Rand Afrikaans University, South Africa. Link: https://goo.gl/ErQgVv

4. Palniappan RM, Karthikeyan S (2009) Bioaccumulation and depuration of chromium in the selected organs and whole body tissues of freshwater fish Cirrhinus mrigala individually and in binary solutions with nickel. J Environ Sci 21: 229-236. Link: https://goo.gl/TVxxa5

5. Rajkowska M, Protasowicki M (2011) Distribution of selected metals in bottom sediments of lakes Ińsko and Wiola (Poland). Ecol Chem Engineer 18: 805-812. Link: https://goo.gl/XKx8Tb

6. Vinodhini R, Narayanan M (2008) Bioaccumulation of heavy metals in organs of fresh water fish Cyprinus carpio (Common carp). Inter J Environ Sci Technol 5: 179-182. Link: https://goo.gl/zvakyT

7. Mansouri BR, Baramaki H, Ebrahimpour M (2011) Acute toxicity bioassay of mercury and silver on Capoeta fusca (black fish).Toxicol Ind Health. Link: https://goo.gl/a9Db71
8. Agency for toxic substances and Disease Registry ATSDR (1999) Toxicological profile for mercury. Atlanta, GA: U.S. Department of Health and Human Services, Public Health Service. Link: https://goo.gl/ypWXqc

9. Ramesh C, Sujatha, Doss KP, Monish T (2001) Cadmium, carcinogen, cocarcinogen and anticarcinogen. India Clin Biochem., 16: 145-152. Link: https://goo.gl/6dmFxh

10. Ting Z, Yu Z, DeLiang LI, Tiao X, LI J (2013) Exposure of silver carp (Hypophthalmichthys molitrix) to environmentally relevant levels of cadmium: hematology, muscle physiology, and implications for stock enhancement in the Xiangjiang River (Hunan, China). Sci China (Life Sci) 56 66-72. Link: https://goo.gl/PMK14y

11. Torres P, Tort L, Fish R (1987) acute toxicity of copper to mediterranear dog fish. Comp. Biochem. Physiol, 86: 169-171. Link: https://goo.gl/vVNLf6

12. Dautremepuits C, Paris PS, Betoulle S, Vernet G (2004) Modulation in hepatic and head kidney parameters of carp (Cyprinus carpio L.) induced by copper and chitosan. Comp. Biochem. Physiol, 137: 325-33. Link: https://goo.gl/Hw8od4

13. Strickland RD, Freeman ML, Gurule FF (1961) Copper binding by proteins in alkaline solution. Anal. Chem. Link: https://goo.gl/EfhhDM

14. Henry RJ, Winkelman JW, (1974) In Clinical Chemistry - Principles and Technics. 2nd edn, Harper and Row. Link: https://goo.gl/1DdCMc

15. Trinder, $\mathrm{P}$ (1969) Ann. Clin. Biochem 6: 24. Link: https://goo.gl/zHpb4C

16. Bergmayer HV (1974) In: Methods of Enzymatic Analysis'. Academic Press, Inc., New York, USA.

17. Young DC, et al. (1975) Clin. Cbem.

18. Benson WH, Baer $\mathrm{KN}$, et al. (1987) Influence of cadmium exposure on selected hematological parameters in fresh water teleost, Notemigous chrysoleucasEcotoxicol. Environ saf 13: 92-96. Link: https://goo.gl/K2w4ZY

19. Partap HP, Bonga SEW (1990) Effect of water- borne cadmium on plasma cortisol and glucose in the cichlid fish, Oreochromis mossambicus. Comp. Biochem.Physiol 95: 313-317. Link: https://goo.gl/CyD5H7

20. Hontela A, Daniel C, et al. (1996) Effect of acute and subacute exposure to cadmium on the inter renal and thyroid function in rainbow trout, Oncorhyncus mykiss. Aqut. Toxicol. 35: 171-182. Link: https://goo.gl/vWndhA

21. Radhakrishaniah K, Venkataramana $\mathrm{P}$, et al. (1992) Effect of lethal and sublethal concentrations of copper on glycolysis in the liver of the fresh water teleost, Labeorohita (Ham). J.Environ.Biol 13: 63-68. Link: https://goo.gl/qPmWCW

22. Hanke W, Gluth G, Bubel H, Muller R (1983) Physiological changes in carps induced by pollution. Ecotoxicol. Environ. Saf 7: 229-241. Link: https://goo.gl/DkErkk

23. Folmar LC, Bonomelli S, Moody T, Gibson J (1993) the effect of short term exposure to three chemicals on the blood chemistry of the pinfish, Lagodon rhomboides. Arch. Environ. Contam. Toxicol 24: 83-86. Link: https://goo.gl/u1uDHc

24. Vutukuru SS (2005) acute effect of Hexavalent chromium on survival, oxygen consumption, Hematological parameters and some biochemical profiles of the Indian major carps, labeo rohita. Int. J.Environ. Res. Public Health 2: 456462. Link: https://goo.gl/QuZatF

25. Kori-Siakpere O, Ake JEG et al. (2006) Sublethal effects of Cadmium on some selected haematological parameters of Heteroclarias. Inter.J.Zool.Reser 2 77-83. Link: https://goo.gl/dWPymy

Copyright: (C) 2017 Rajeshwari S, et al. This is an open-access article distributed under the terms of the Creative Commons Attribution License, which permits unrestricted use, distribution, and reproduction in any medium, provided the original author and source are credited.

Citation: Rajeshwari S, Sevarkodiyone SP (2017) Biochemical parameters of Common Carp (Cyprinus Carpio) exposed to Cadmium change to the leaf extract of Abutilon indicum. J Clin Microbiol Biochem Technol 3(2): 054-057. 